\title{
Conocimiento y empleo de medidas de apoyo a las pymes en Argentina
}

Familiarity with and Use of Support Measures for SMEs in Argentina Conhecimento e uso de medidas de apoio para PMEs na Argentina

Hernán Revale

Universidad Nacional de Rafaela, Argentina

E-mail: hernanrevale@unraf.edu.ar

\section{Rubén Ascúa}

Universidad Nacional de Rafaela, Argentina

E-mail: rubenascua@unraf.edu.ar
Fecha de recepción: 31/10/2018 Fecha de aceptación: 29/02/2020

\section{Resumen}

El presente trabajo propone hacer un relevamiento respecto de conocimiento y empleo de medidas de fomento a las pymes y relacionarlos con variables estructurales de las mismas. Para ello, a fines de 2017 y comienzos de 2018 se realizaron encuestas a una muestra representativa de pymes de la ciudad de Rafaela. En particular, se relevó sobre conocimiento y utilización de líneas de apoyo financiero, y sobre la ley Pyme 27264, la cual reporta de ciertos beneficios a aquellas empresas registradas en la AFIP como categoría pyme.

Se observó que las empresas del sector industrial principalmente y de mayor tamaño son aquellas que conocen y utilizan en mayor medida tales tipos de políticas. Se encontró que, en términos generales, las líneas de financiamiento a las pymes son poco conocidas, y los beneficios de la ley Pyme son utilizados en una medida mayor. De los beneficios destacaron el uso del descuento del «Impuesto al cheque» del Impuesto a las Ganancias, diferir el pago del IVA por 90 días, y el descuento del Impuesto a las Ganancias de la inversión en maquinaria o infraestructura.

Además, se analizaron asociaciones entre variables categóricas que representan el aprovechamiento de las medidas estudiadas y otras varia-

Palabras clave - pymes

- financiamiento políticas bles de características de interés de las empresas. Los resultados obtenidos abren nuevas preguntas a fines de ahondar en las justificaciones y la causalidad de las asociaciones. 
Keywords

- SMES

- financing

- policies

\section{Abstract}

This research work aims to assess the familiarity with and the use of measures to promote SMEs, and relate them to their structural variables. With this purpose, at the end of 2017 and at the beginning of 2018, a survey was conducted on a representative sample of SMEs from the city of Rafaela, which were especially asked about the familiarity with and use of financial support programs, as well as about the Law No. 27.264 (commonly known as SME Law), which yields several benefits to companies registered as SMEs in AFIP.

It was observed that companies in the industrial sector, mainly, and those of greater size are the ones that are familiar with and use to a greater extent such types of policies. In general terms, it was found that the financing programs for SMEs are not well-known, and that the benefits of the SME Law are used to a greater extent. Among these benefits, the discount of the check processing tax of the Income Tax, the access to 90-day deferred payment of the VAT, and the discount of the Income Tax derived from the investment in machinery or infrastructure were highlighted.

In addition, the relationships between categorical variables that represent the use of the measures studied and other variables of special interest for the companies were analyzed. The results raise new questions to delve into the reasons and the causes of those relationships.

\section{Resumo}

0 presente trabalho propõe relevar sobre conhecimento e uso de medidas de fomento às PMEs, e relacioná-Ios com variáveis estruturais das mesmas. Para isso, a finais do 2017 e começos do 2018 realizaram-se enquetes a uma amostra representativa de PMEs da cidade de Rafaela. Em particular, relevou-se sobre conhecimento e uso de linhas de apoio financeiro, e sobre a "Lei PME" (№ 27.264), a que informa de certos benefícios à aquelas empresas registradas na AFIP (Administração Federal de Ingressos Públicos) como categoria PME.

Observou-se que as empresas do setor industrial principalmente e de maior porte são aquelas que conhecem e usam mais esse tipo de políticas. Achou-se que, em termos gerais, as linhas de financiamento para PMEs são pouco conhecidas e que os benefícios da Lei das PMEs são mais utilizados. Dos benefícios salientaram o uso do desconto do "Imposto ao cheque" do Imposto de Renda, adiar o pago do IVA (Imposto ao Valor Agregado) por 90 dias, e o desconto do Imposto de Renda do investimento em maquinária ou infraestrutura.

Aliás, analisaram-se associações entre variáveis categóricas que representam 0 aproveitamento das medidas estudadas e outras variá-

Palavras-chave

- PMES

- financiamento

- políticas veis de características de interesse das empresas. Os resultados obtidos abrem novas perguntas com 0 objetivo de aprofundar nas justificações e a causalidade das associações. 